Тетяна КУЗНЕЦЬ,

orcid.org / 0000-0002-9282-110X

доктор історичних наук,

професор кафедри історії України

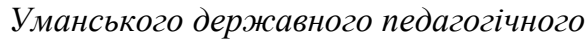
університету імені Павла Тичини

(Украӥна. Умань)

tetiana.kuznets@gmail.com

Ірина ГОНЧАРУК,

мazicmp icmopii

Уманського державного педагогічного університету імені Павла Тичини

(Украӥна, Умань)

irinagoncharuk22@gmail.com

\title{
ДАНИЛО ДЕМУЦЬКИЙ В ІСТОРІЇ ТА КУЛЬТУРІ УКРАЇНИ
}

У статті проаналізовано основні віхи життя та діяльності украӥнського кінооператора та фотографа Данила Порфировича Демуиького. Підкреслено внесок Д. Демуцького у розвиток кінематографу України першої половини ХХ сm. Наголошується на тому, що незважаючи на нововведення внесені Данилом Порфировичем для професійного розвитку кінооператорів, його ім'я залишилося маловідомим у світлі діячів українського кінематографу та культури загалом. Результатом наукової розвідки є пробудження майже крізь століття тиші імені Данила Порфировича, як яскравого представника не тільки родини Демуиьких (відомої сім'і, яка подарувала Україні двох відомих діячів мистецтва - батька Порфирія та сина Данила), а и як професіонала та бория за справу свого життя.

Ключові слова: культура, Данило Демуиький, кінооператор, фотограф, кінофільм, заслання.

Tetiana KUZNETS, orcid.org / 0000-0002-9282-110X

Doctor of Historical Sciences, Professor of the Department of History of Ukraine Pavlo Tychyna Uman State Pedagogical University

(Ukraine. Uman) tetiana.kuznets@gmail.com

Irina GONCHARUK

Master of History

Pavlo Tychyna Uman State Pedagogical University (Ukraine. Uman) irinagoncharuk22@gmail.com

\section{DANYLO DEMUTSKYI IN HISTORY AND CULTURE OF UKRAINE}

Danylo Demutskyi, like his famous father Porfyrii Demutskyi who was folklorist and musician, tried to enrich Ukrainian art with novelty throughout his life. His activities included cinema and photography. In these areas, he managed to reach a real apogee and make a significant contribution to the development of culture in Ukraine in the twentieth century and the formation of the profession of cinematographer and, in general, the film industry to a new level of perception. The article presents an analysis of the main pages from the life and work of Ukrainian cinematographer and photographer Danylo Porfirovych Demutskyi, as well as emphasizes the contribution of the "operator-magician" to the development of Ukrainian cinema in the first half of the twentieth century.

Today, the name of the representative of the Demutskyi family - Danylo Porfyrovych, appears before us from a new point of view. Though he has long been absent from the living, the cause of life is being revived with a new force. This is how we must remember the one who challenged the totalitarian regime and all possible troubles in the life of 
man, while preserving his own "I", leaving the pictorial heritage of Ukraine, depicting the native land in all its manifestations.

Danylo Demutskyi's story was no less complicated than his father's, and sometimes even more difficult. He was sentenced to three unjustified arrests and the stigma of a "socially dangerous element", exile to Tashkent and a ban on engaging in professional activities. It is always difficult to start at first, especially when you are far from your homeland, which inspires new discoveries, which is a muse for creating masterpieces of cinema. However, without giving up for a moment, he continued developing his hobby - cinema.

Danilo Porfyrovych was one of those people who were ahead of his time. Thanks to him, the world saw the legendary films that showed the existence of Ukrainian people. Thanks to the talent of the magician cameraman, even black-and-white shots came to life in front of the audience. Discovering the world of photography from early childhood, he brought to life the surrounding paintings and did it like no other. Many people familiar with the skill of Demutskyi Jr. attribute it to the famous meters of domestic cinema. The result of scientific research is the awakening of interest in the name of Danylo Porfirovych and his talent as a cinematographer, as well as as a bright representative not only of the Demutsky family (a famous family that gave Ukraine two famous artists - father Porphyry and son Danylo), but and as a professional and fighter for the cause of his life.

Thus, thanks to the efforts of Danylo Porfyrovych and his camera, many well-known films of Ukrainian and Soviet cinema of the 1920s and 1930s were shot. Unfortunately, as sometimes happens with professionals, recognition by the authorities and wild popularity on movie screens came after Demutsky's death, because two hours later he received the highest award - the title of Honored Artist of Ukraine and Uzbekistan.

Key words: culture, Danylo Demutskyi, cinematographer, photographer, film, exile.

Постановка проблеми. Перша половина XX століття ознаменувалася бурхливим розвитком в культурному житті України. Розвивалися всі сфери: музична, живописна, архітектурна, літературна та інші, кожна 3 яких потребувала уваги професіоналів. Не став винятком й кінематограф, який почав розвиватися швидкими темпами. 3'являються перші українські кінокартини, над якими невпинно працювали режисери, оператори, сценаристи. Серед майстрів своєї справи можна виокремити відомого у першій половині XX століття кінооператора Данила Демуцького.

Аналіз досліджень. Сучасна історіографія майже не включає в себе досліджень про діяльність Данила Демуцького. Здійснивши своєрідний переворот у розвитку української кінооператорської справи, він залишився в тіні уваги дослідників історії кіно. Наукових праць, в яких також висвітлено основні віхи життя Д. Демуцького є не багато. Серед них варто виокремити праці таких дослідників: Т. Дерев’янка (Дерев'янко, 2001), Л. Брюховецької (Брюховецька, 2003), С. Тримбача (Тримбач, 2018), Л. Кохна (Кохно, 1965), А. Пащенко (Пащенко, 2015), О. Попельницької (Попельницька, 2010), Б. Вербжицького (Вержбицький, 2015) та ін. У наукових доробках кожного 3 перерахованих дослідників життєвого та творчого шляху Д. Демуцького звертається увага на окремі періоди його життя. Також цінними стали наукові 
праці, в основу яких покладено враження поціновувачів таланту Д. П. Демуцького. Так, у публікаціях П. Масохи (Масоха, 1970) та А. Лазового (Лозовий, 2013) збереглися спогади О. Довженка, О. Калюжного та слова вдячності одного із учнів кінооператора С. Параджанова.

У 2011 році світ побачила збірка «Українське німе» (Українське німе, 2011), у якій поряд 3 іншими відомими представниками кіноіндустрії чи не вперше було виведено із тіні постать Данила Порфировича. У цьому виданні великий акцент зроблено на особливостях роботи Демуцького як фотомайстра 3 об’єктивом монокль, а також на його індивідуальному підході до зйомок кожного нового фільму.

Мета статті полягає у висвітленні професійної діяльності Данила Демуцького, акцентуванні важливості його внеску у розвиток українського кінематографу першої половини ХХ ст.

Виклад основного матеріалу. Будучи сином відомого батька, музикантафольклориста та керівника Охматівського хору Порфирія Демуцького, Данило Порфирович не залишився в тіні його слави, а навпаки вийшов на новий рівень, працюючи та розвиваючи маловідому на початку XX століття сферу українського мистецтва - кінематограф.

Від народження (16 (4) липня 1893 р.) Данило Демуцький зростав у лоні поваги та праці на благо мистецтва (Кізченко, 2004: 331). I батько музикантфольклорист Порфирій Данилович, i мати знавець української народної культури Устинія Данилівна, виховували в синові таку ж неослабну любов до мистецтва, яка була притаманною ним самим. У садибі Демуцьких в с. Охматів завжди гостювали відомі діячі української культури кінця XIX - початку XX століття, від яких він міг почерпнути знань. 3 дитинства спостерігав тісну співпрацю батька Порфирія Даниловича з власним хором, його фольклорноетнографічну діяльність, проте не виявляв бажання продовжувати музичну справу батька. Данила приваблювало мистецтво в інших його проявах картини, фотографії, пізніше й кіно. Цікавим фактом $є$ те, що перший фотоапарат, яким Демуцький-молодший знімав фотокартини, він отримав у 
подарунок саме від батька ще у восьмирічному віці, під час навчання у третьому класі гімназії (Дерев’янко, 2001: 28). 3 того часу Данило більше не розлучався 3 ним.

Освіту Данило Демуцький здобував спочатку вдома, далі навчався протягом 1911-1917 pp. у Другій Київській гімназії. Вищу освіту Данило Порфирович подібно батькові отримав у Київському університеті. Спочатку він вступив на медичний факультет, проте через рік змінив медицину на юридичну освіту (Кізченко, 2004: 331). Під час навчання в Києві він продовжував розвивати своє хобі, вступивши до місцевого товариства фотоаматорів. Його успіхи у роботі над фотокартками були вражаючими. Вже 1913 р. Данило Порфирович вперше представляв свої роботи на Всеросійській виставці художників світлопису. Було передано для виставки чотири майстерно зроблені фотографіі, які автор зняв з використанням об’єктиву «монокль» (Дерев’янко, 2001: 28). Це були його перші спроби фотографування подібним об'єктивом, який назавжди залишиться в його кар'єрі фотографа. Талант був помічений всіма верствами українського населення, адже його фотокартини друкувалися у фахових журналах, таких як «Вестник фотографии» та «Фото для всех» (Кізченко, 2004: 331). На сторінках популярного у 20-30-х роках ХХ століття журналу «Кіно» в розділі «Люди екрану» було видрукувано статтю, присвячену творчому шляхові Данила Демуцького. В ній містилися спогади очевидців (записані кореспондентами журналу) про фотографії Данила Порфировича, які були представленні у виставкових залах різних міст: «Ті роботи ..., що на виставках ... були показані, є типовими взірцями фотоімпресіонізму, що панував та й тепер панує в фотографії» (Брюховецька, 2018).

Перш ніж досягнути визнання, Демуцький пройшов через непорозуміння від колег по цехові. Спочатку його роботи не викликали бажаного захоплення в українських фотомайстрів. Таке ставлення пояснюється незвичною манерою фотографування моноклем. Визнання на батьківщині прийшло до Демуцькогомолодшого після 1925 р. За значний внесок у розвиток фотомистецтва Данило Порфирович був удостоєний нагородження золотою медаллю на Міжнародній 
виставці декоративного мистецтва, яка проходила в Парижі у 1925 p. (Брюховецька, 2018). На виставці було представлено декілька робіт митця. Після цього роботи Данила Демуцького виставлялися на фотовиставках Києва, Харкова, Москви та Санкт-Петербургу.

Майстерність Данила Порфировича як фотографа залишилася в пам'яті не тільки фотоплівки, а також у спогадах та захоплених відгуках від побачених його робіт на виставках. Так, Б. Вержбицький у своїй статті, присвяченій творчій діяльності Д. Демуцького, перебуваючи під враженнями від робіт фотомайстра, зазначав: «...в його фотороботах була прихована особлива енергія» (Вержбицький, 2013). Ця «енергія» захоплювала чимало поціновувачів мистецтва фотографії першої половини XX століття.

Данило Демуцький певною мірою був пов'язаний з діяльністю театру «Березіль». Починаючи з 1921 р. він працював в цьому культурному осередкові. Разом 3 відомим художником В. Меллером вони займалися художнім оформленням спектаклів, які ставилися на сцені театру.

Значні досягнення Данила Порфировича у майстерності фотографування можна прослідкувати завдяки фотоматеріалам, зібраним ним у 1929-1930 роках. Ці унікальні зображення були внесені як додатки до колективної монографії, присвяченої історії селища Старосілля, що на Чернігівщині (Демуцький, 1931). Особливо, вражає чіткість зроблених Демуцьким не тільки фотокарток, а й схематичних замальовок, які вдало доповнюють видрукувану історичну працю.

Захоплення фотографуванням підштовхнуло Данила Демуцького до справи всього його життя - кінематографа, який приніс йому визнання. Першою кінокартиною, над якою він працював вже помічником кінооператора Й. Рона, був фільм «Вася-реформатор», знятий 1926 р. у співпраці з О. Довженком на Одеській кіностудії (Кізченко, 2004: 331). Після завершення роботи над цією кінострічкою, співпраця між Демуцьким та Довженком була звичною справою. Разом вони зняли такі кінофільми: «Арсенал» (1929 р.), «Земля» (1930р.) та «Іван» (1932 р.) (Кізченко, 2004: 331). Залишилися спогади Олександра 
Довженка про майстерність Данила Демуцького під час їхньої спільної праці на знімальному майданчику. Зокрема він занотував: «Я думаю, що оператор тоді може бути повноцінним, ..., якщо ви, спрацювавшись із ним, можете бути впевнені, що він також розуміє всі деталі вашого задуму...» (Попельницька, 2010: 448-449). Про гармонічну співпрацю та дружні відносини між Довженком та Демуцьким на знімальному майданчику відгукувалися всі учасники кінокартин. Так, один із головних акторів кінострічки «Земля» П. Масоха називав цей творчий тандем «щасливим творчим здруженням» (Брюховецька, 2018), описуючи Данила Порфировича як чуйну людину, яка «своєю майстерністю увінчує на плівці мистецьку славу свого режисера [О. Довженка]» (Брюховецька, 2018). Професіоналізм Данила Демуцького як кінооператора можна прослідкувати й в інших художніх фільмах, знятих протягом 1926-1928 pр. Це зокрема, такі: «Свіжий вітер», «Два дні» та «Лісова людина» (Кізченко, 2004: 331). Роботи Данила Порфировича були приреченими на успіх. Провідні режисери українського кінематографа на чолі 3 О. Довженком запрошували його до співпраці, а прізвище Демуцьких продовжувало звучати в культурній буденності України першої половини XX століття.

Досягнувши значного успіху після виходу на екрани кількох своїх кінострічок, Данило Демуцький страждав від постійних утисків влади та переслідувань зі сторони НКВС (Бундак, 2013: 93). Вперше його було заарештовано 1932 р. Данила Порфировича звинувачували у розголошенні таємної інформації допиту, а також у приховуванні забороненого у 1920-1930ті pр. сценарію, написаного репресованим драматургом та режисером Ф. Лопатинським для майбутнього фільму «Україна». Протягом чотирьох місяців оператор перебував під арештом. Не маючи переконливих доказів вини Демуцького, влада видала наказ про його звільнення. Але на цьому відносини між НКВС та Данилом Порфировичем не завершилися.

Як зазначали дослідники його життєвого шляху, 1935 р. Д. П. Демуцький «за невідомих причин» переїздить до Ташкенту, де продовжує займатися 
зйомками кінокартин (Кізченко, 2004: 331). Проте, вже у другій половині XX століття з'являються нові, раніше приховані дані біографії молодшого Демуцького. Серед них було виявлено справжню причину раптового переїзду фотомайстра та кінооператора до Узбекистану. Справа в тому, що 19 грудня 1934 р. Данила Демуцького було вдруге безпідставно заарештовано та відправлено в заслання під клеймом «соціально небезпечного елемента» (Вержбицький, 2015: 101). Причину арешту було названо таку: Данило Демуцький підтримував тісний зв'язок зі своїм далеким родичем по батьковій лінії К. Ф. Демуцьким, який був членом білоемігантської організації (Попельницька, 2010: 449). Насправді ж, підстава для арешту була не вмотивована, адже оператор Демуцький не був у зв'язку із названою особою $\mathrm{i}$ бачився $з$ родичем один раз у житті, ще у дитинстві. 3 особистих записів Данила Порфировича про період арешту стає відомо, що перш ніж виїхати до Ташкенту (Узбекистан), Демуцький був знову ув'язнений протягом чотирьох місяців. Також він згадував, що за період арешту відбувся тільки один допит, під час якого слідчі запитували в нього про власну родину: «Я повинен найдетальніше перерахувати всіх своїх родичів як близьких, так і далеких 3 боку батька і з боку матері, живих і давно померлих, імена та ступінь спорідненості яких я часто ледве міг знати» (Дерев'янко, 2001: 29). На перший погляд стає незрозумілим, навіщо слідчим знадобилася подібна інформація. Проте, все робилося з однією метою - знайти причину, з якої можна було вислати Данила Демуцького з України. Так як мати Данила походила 3 поміщицької сім'ї, а батько мав дворянський титул, то родина Демуцьких автоматично зараховувалася до числа «соціально-небезпечних елементів», до яких в описуваний період не могла схвально ставитися Радянська влада. Таким чином, знайшовши «поважну» причину, державно-репресивна система все ж відправила Данила Демуцького у заслання.

Втретє Данила Порфировича було заарештовано 1937 р., коли він перебував на засланні в Узбекистані. Причиною арешту стали невідомі й до сьогоднішнього дня свідчення психічно хворої людини, на підставі яких 
оператора було позбавлено волі протягом сімнадцяти місяців. Після звільнення Демуцького було повністю реабілітовано та дозволено повертатися до України. Проживши в Києві протягом декількох років, з початком Другої світової війни Данило Демуцький разом 3 дружиною Валентиною знову повертаються до Ташкенту.

Перебуваючи упродовж кількох років далеко за межами рідного краю, Данило Порфирович намагався домогтися від влади пояснення стосовно того, чому його діяльність в Україні заборонена, зняті фільми рідною мовою заборонені, а його самого вислали за межі України. У 1946 р. митець надіслав офіційного листа до генерального прокурора СРСР, у якому прохав про перегляд його справи та винесення остаточного вироку, який за словами самого Д. П. Демуцького: «змиє, нарешті, 3 мене ганебну пляму «соціально небезпечного елемента», присвоєну мені цим рішенням» (Вержбицький, 2015: 101). Автор листа також зазначав, що одинадцять років заслання є достатнім терміном аби переглянути раніше прийняте рішення, яке не мало жодного аргументованого пояснення. В кінцевому результаті Данило Демуцький зумів домогтися перегляду вироку і вже 1946 р. він отримав дозвіл знову займатися операторською справою в Україні.

Повернувшись до України, Данило Порфирович продовжує займатися улюбленою справою. На Київській кіностудії були відзняті декілька фільмів за участі Демуцького-молодшого. Серед них виокремлюють: «Подвиг розвідника» (1947р.), «У мирні дні» (1951р.), «Тарас Шевченко» (1951р.). За участь у зйомках кінокартини «Тарас Шевченко», яка стала першим кольоровим фільмом, знятим українськими кінематографістами, Данило Демуцький у 1952 p. став лауреатом Сталінської премії першого ступеня (Кізченко, 2004: 331). Його роботу над кінострічкою «У мирні дні» також було високо оцінено на Шостому Міжнародному фестивалі в Чехії (м. Карлові Вари) та удостоєно премії (Кізченко, 2004: 331). Нарешті, Данило Порфирович почав отримувати гідні нагороди за свою майстерність. Проте, одна 3 найбільш важливих для діячів культури нагород знайшла свого власника тільки після смерті. 
Заборона знімати українські кінострічки, заслання до Узбекистану, переслідування владою - все це неабияк засмучувало молодого Демуцького. Проте вірною соратницею та підтримкою для кінооператора була його дружина - Валентина Михайлівна Демуцька (Вержбицький, 2013). На жаль не виявлено жодних відомостей про їі батьків та діяльність при житті, окрім слів вдячності, які проголошував відомий діяч кіно С. Параджанов, відвідавши іï у десяту річницю смерті Д. П. Демуцького. Він зазначав: «Вы одна из тех прекрасных муз художника, вы тот колоссальный друг, которого иногда ищет художник всю жизнь и не находит» (Вержбицький, 2013). Поки що не вдалося відшукати відомостей i про спільних дітей Данила Порфировича та Валентини Михайлівни Демуцьких.

Помер Данило Демуцький на батьківщині, у Києві 7 травня 1954 р. (Кізченко, 2004: 331). Причиною смерті, як і у батька, було серце. Протягом життя кінооператор переніс три інфаркти, а останній став фатальним. Похований поряд з батьком, відомим діячем музичного мистецтва України Порфирієм Даниловичем Демуцьким. Через дві години після смерті Д. Демуцького йому було присуджено посмертно звання Заслуженого діяча мистецтв України та Узбекистану. Також у 1992 р. вийшла в прокат біографічна кінострічка «Нехай святиться ім'я твоє», присвячена життєвому та творчому шляхові відомого кінооператора першої половини XX століття (режисер та автор сценарію - Н. Акайомова). Біографічний фільм був схвально оцінений кінокритиками, отримавши чимало позитивних відгуків. На жаль, сьогодні не залишилося жодної копії цієї кінострічки. Після смерті режисерки $\mathrm{H}$. Акайомової у 2012 р. безслідно зникла остання копія біографічної кінострічки про Д. П. Демуцького.

Отже, життєвий шлях Данила Демуцького був не менш гірким, ніж у його батька. На долю кінооператора випали арешти, заборона працювати та проживати на Батьківщині. Сферою зацікавленості, на відміну від батька (який присвятив себе дослідженню пісенного минулого українського народу), було буття, яке йшло навздогін з часом. Мало хто знає його ім'я, та він здобув за 
життя більшої слави, ніж його сучасники. Данило Демуцький жив фотографією, фіксацією природи рідного краю. Він був тим, хто випередив час, адже чи не першим створив картину, яка оживала на очах. Навіть чорно-білі соняшники набували яскравих барв та розквітали на екранах перед глядачами. I це все завдяки майстерності оператора Демуцького.

Данило Порфирович Демуцький протягом життя був відданим служителем мистецтва. Розвиваючи та прославляючи українську культуру далеко за межами батьківщини, йому вдалося досягнути успіху у двох її сферах - фотографуванні та кіномистецтві. Якщо любов до фотографії з'явилася ще в дитячі роки, то захоплення Д. П. Демуцького кінематографом почалося у досить зрілому віці. Будучи уже відомим фотомайстром, який створив власний стиль у фотографуванні, отримавши у спадок від батька любов до мистецтва та маючи грунтовну освіту, у віці тридцяти двох років Данило Порфирович спробував себе у абсолютно новій сфері української культури, яка тільки почала активно розвиватися.

Серед багатого спектру професій в кіноіндустрії Данило Демуцький обрав кінооператорську справу. Вперше 3 кіноапаратом Данило Порфирович познайомився завдяки відомому у 1920-1930-х рр. оператору художніх фільмів О. Калюжному. Саме той привив майбутньому метрові операторської справи любов до кінокамери (Шульгіна, 2016: 99). Перш ніж глядачі познайомляться 3 відзнятою та відредагованою кінострічкою, над її створенням працює декілька професіоналів. Серед них і оператор фільму. Не легку працю кінооператора широковідомий кінокритик першої половини XX століття Р. Юренев описував так: «Мабуть, єдиними справжніми професіоналами були кінооператори. Вони вміли наводити фокус, рівномірно крутити ручку апарату, знали хімікалії для проявки і друку» (Шульгіна, 2016: 99). Перед ними постає нелегке завдання відзняти кадри кінострічки таким чином, щоб максимально передати глядачеві відчуття навколишнього світу (подиху вітру, шум води, спів птахів тощо). Завдяки майстерній роботі кінооператора стає можливим відчуття тієї атмосфери, відносин образів та персонажів, які за задумами сценаристів, 
режисерів та інших учасників знімального майданчика мають відчуватися під час перегляду готової кінокартини. На жаль, важливість внеску оператора у знімання кінофільму була визнана тільки у 1920 р. (Пащенко, 2015: 93). До цього часу всі лаври за вдале, професійне знімання фільмів надавалися тільки режисерові, а робота інших працівників кіностудії, зокрема кінооператорів залишалася в тіні. 3 цієї причини імена деяких операторів, які працювали в перші десятиліття XX століття, назавжди залишилися забутими.

Варто звернути увагу на те, що захоплення справою кінооператора почалося у молодого Демуцького 3 фотографії. Данило Порфирович мав неабиякі успіхи у цій сфері, брав участь у численних фотовиставках та отримував нагороди за свої фото картини. Базові знання i навики у фотографуванні він отримав будучи учнем школи фотографії у товаристві «Дагер», що діяла під керівництвом М. Петрова (Брюховецька, 2003: 265). Удосконалити навики роботи з фотоапаратом йому вдалося у фотолабораторії, що перебувала у віданні Всеукраїнської академії наук, в якій Данило Порфирович працював упродовж 1921-1925 років (Тримбач, 2018) Найпоширенішим жанром фоторобіт Демуцького були пейзаж та портрет. Також, Данило Порфирович самостійно опанував нелегку техніку зйомки за назвою «монокль» й створив абсолютно новий напрямок у фотомистецтві.

Незмінним наставником Данила Порфировича був вже згадуваний О. Калюжний, який відіграв значну роль у становленні багатьох майбутніх майстрів української кінематографії. Саме він навчив Демуцького творчо підходити до різноманітних особливостей ідейного та художнього задуму фільму, техніки його інтерпретації та зйомки. Переглядаючи та професійно вивчаючи всі деталі нових кінострічок, знятих О. Калюжним, Данило Демуцький набирався досвіду для власних фільмів.

За період свого становлення як майстра операторської справи Данило Порфирович мав змогу працювати з різними жанрами кінофільмів початку XX століття. Це були й драми, й комедії, й фільми на історичну тематику. Найбільшої популярності Д. Демуцькому принесли останні. Серед відомих 
історичних фільмів, знятих оператором Демуцьким, вирізняють: «Два дні» (1927 р.), «Арсенал» (1929 р.) та «Земля» (1930р.). Кінострічка «Два дні» режисера Г. Стабового є оригінальним зразком українського історичного фільму першої половини XX століття. В центрі кінокартини є революція та зміни, які почалися після ії завершення. Головним героєм постає простолюдин на ім’я Антон, який зазнав знущання від представників «панського світу», за що помстився спаленням їхніх маєтків. На перший погляд сюжет $є$ поширеним у тогочасній кіноіндустрії, тому постає питання: в чому ж його особливість? На сторінках американської газети «Нью-Йорк Геральд Триб’юн», яка виходила друком з 1887 р., видрукувано таке: «Фільм “Два дні” відрізняється ... тим, що він концентрує драматизм не на масі, а на індивідуумі» (Фоміченко, 1929: 2). Дійсно, в порівнянні з іншими подібними за сюжетною лінією кінофільмами радянського періоду, в яких увага глядачів була прикутою до загальних подій, у історичній кінострічці «Два дні» фокусується увага на окремій особистості, від якої проводиться паралель до загальної ситуації в країні. Під час знімального процесу цього кінофільму Данило Демуцький постав не тільки як професійний кінооператора, а також як знавець внутрішнього, психологічного світу людини. Йому вдалося навіть крізь чорно-білий об'єктив камери чітко та чуттєво передати всі емоції та переживання героїв кінокартини.

Фільм «Два дні» здобув загальне визнання, якому посприяв не тільки режисер, а й вся знімальна група разом з оператором Д. Демуцьким. Серед особистих записів Данила Порфировича є такий: «Працюючи, я не помітив, як пролетіла ніч. Переді мною весь час стояло обличчя головного героя ...,що відбивало в собі, як у дзеркалі, велику драму подій» (Кохно, 1965: 22). Використовуючи масив здобутих раніше знань, він зумів зняти фільм так, щоб були помітними навіть найменші деталі: від індивідуальних зовнішніх рис та внутрішніх переживань головного героя до картини загального стану населення.

Повною протилежністю «Двом дням» $є$ інша історична кінострічка, відзнята оператором Данилом Демуцьким та режисером Олександром 
Довженком - «Арсенал» (Пащенко, 2015: 97). Якщо в попередньому фільмі спостерігалося прагнення передати життя окремої особистості на тлі революції, то в «Арсеналі» все навпаки. Тут простежується символічне зображення окремих героїв та їх проблем, переживань, що в сукупності й складають революційні настрої населення. В основу сюжету фільму покладено детальний опис придушення повстання робітників на київському заводі «Арсенал» (Антоненко, 2016). Всі події, зображені в кінофільмі $\epsilon$ ритмічними, наповненими портретними («плакатними») кадрами. Для того, аби фільм вийшов таким, довелося чимало часу попрацювати операторові. Данило Порфирович в повній мірі справився 3 поставленими Довженком задачами. Образність, притаманна для експресіоністів, оригінальність розташування декорацій, майстерна операторська та режисерська робота зуміли вивести «Арсенал» на світову арену, далеко від межі діяльності радянської пропаганди, надавши кінокартині нового дихання.

Ще одним історичним кінофільмом, професійно знятим Д. Демуцьким у співпраці з О. Довженком, став широковідомий у світі фільм «Земля». В цій кінострічці особливо помітною стає робота оператора. Головна заслуга Демуцького в тому, що йому вдалося зробити неможливе - зняти насичені портрети за допомогою тонких світлових нюансів. В цьому випадку в нагоді Данилу Порфировичу став монокль (Безсмертний-Анзіміров, 2016). Саме завдяки використанню такого об'єктиву, Демуцькому вдалося зобразити пейзажі кінострічки у легкій димці, а головних героїв - у м'яких, дещо приглушених тонах. Наскрізною ниткою через весь фільм простежуються справжні барви природи, вони ніби оживають на кіноекрані перед глядачами. Досягнути таких ефектів стало можливим тільки за умови високого професіоналізму оператора фільму, яким відзначався Данило Порфирович. Кінострічка «Земля», над створенням якої невпинно працювали двоє метрів вітчизняного кіно - Олександр Довженко та Данило Демуцький, принесла їм популярність та визнання далеко за межами України. За результатами міжнародних опитувань, проведених після прем'єри кінокартини, українська 
«Земля» увійшла до списку дванадцяти найкращих кінофільмів початку XX століття і залишається у цьому переліку до сьогоднішнього дня.

Оператор Демуцький був великим майстром своєї справи. Його талант позитивно оцінено відомими метрами українського кінематографа першої половини XX століття. Підтвердження цьому знаходимо в листі одного з його поціновувачів - О. Довженка до Данила Порфировича напередодні початку роботи над фільмом «Життя в цвіту». Він писав: «Дуже прошу тебе, Данило, допоможи мені. Зніми велику повідь з почуттям і радістю хлопчика... Щоб була ширина, щоб було весело» (Брюховецька, 2003: 263). Також в листі Довженко наголошував на виключній професійній майстерності Демуцького, зазначаючи: «Зніми мені ... так, як тільки ти вмієш» (Брюховецька, 2003: 263). Схвально оцінював працю Д. Демуцького й відомий кінооператор XX століття О. Антипенко. Перебуваючи під враженнями від перегляду кінокартини О. Довженка «Земля», в якій оператором був Д. Демуцький, він писав: «Як це зробив Демуцький? Не знаю. Кіносекрет...» (Вержбицький, 2015: 99). За свідченнями О. Антипенка, Данило Порфирович був гідним майстром своєї справи, адже навіть звичайні екранні епізоди, які він знімав, поставали в кадрі справжніми, «живими», наповненими природними барвами. Порівнюючи кінокартини, зняті Демуцьким, з пізнішими роботами інших операторів, він зазначав: «Я бачу в сучасних фільмах соняшники. Зняті на кольорову плівку. Вони здаються пофарбованими», а в Данила Порфировича: «...завжди бачу соняшники кольоровими...» (Вержбицький, 2015: 99).

Данило Демуцький, подібно батькові Порфирію Даниловичу, знайшов улюблену справу, яку проніс крізь все життя. Переживаючи тиск влади та репресії стосовно діячів культури першої половини XX століття, він знову й знову повертався до кіноіндустрії. Перебуваючи певний період часу в засланні до Ташкенту (як зазначалося раніше), Данило Порфирович не припиняв знімати фільми та ділитися набутими знаннями зі своїми новими колегами по знімальному майданчику. Проте, перш ніж знімати кінострічки в Узбекистані, Демуцькому довелося пережити арешт та ув'язнення в Ташкенті (Дерев'янко, 
2001: 29). Спекотні камери, відсутність чистої питної води та тюремна антисанітарія назавжди залишили слід в пам'яті та на здоров’ї Данила Порфировича. Незважаючи на всі негаразди першого року заслання, Демуцькому-молодшому пощастило познайомитися 3 багатьма видатними митцями Узбекистану, які за свої художні праці також потрапили до в'язниці. Саме завдяки новим друзям він зумів вибратися із тюремної камери та повернутися у мистецтво. Спочатку це була фотографія, журналістика, а вже пізніше повнометражні фільми.

Працюючи фотокореспондентом та спілкуючись із населенням у Ташкенті, Данило Демуцький зацікавився дослідженням узбецького фольклору. Мабуть давалися взнаки спогади 3 дитинства, коли був присутнім при збиранні фольклору батьком Порфирієм Демуцьким. Зібрані матеріали надихнули його на зйомку декількох кінокартин: комедії «Насреддін у Бухарі», «Тахір і Зухра» (Брюховецька, 2003: 264). Фільми були наповнені специфічним східним колоритом та позитивно сприйняті місцевим населенням. В автобіографії Данила Демуцького залишилися записи, в яких зазначена його діяльність під час заслання у Ташкенті. Знаходимо таке: «Моя праця ... дістала загальне схвалення, і маю надію, що поверне мені те становище в радянській кінематографії, яке так несправедливо було відібране в мене...» (Брюховецька, 2003: 264). Таким чином, замість розчарування внаслідок заслання далеко від рідного краю, Данило Порфирович обирає шлях невпинної праці на благо улюбленої справи та розвитку української культури загалом.

Данило Демуцький, маючи чималий масив знань у сфері кіноіндустрії, полюбляв ділитися ними зі своїми молодими колегами. Дослідники біографії Данила Порфировича зазначають про дружні відносини його 3 майбутнім відомим діячем кіно - С. Параджановим (Брюховецька, 2003: 266). Він був частим гостем в будинку Д. П. Демуцького та слухачем його розповідей про кіно. Зі щирою вдячністю він звертався до родини Демуцьких зі словами: «Ви прийняли нас у своєму домі. Ви нам показали красу, навчили відчувати красу, полюбити Схід» (Вержбицький, 2015: 102). Таким запам'ятали Данила 
Порфировича не тільки його учні, а також колеги. «Демуцький непересічний майстер... в його руках об'єктив знімальної камери так само слухняний, як пензель в руці живописця», - писали кореспонденти журналу «Кіно» (1927р.) (Лозовий, 2013). Він, подібно відомому батькові, зумів зробити все, що було необхідним аби голосно заявити на весь світ про існування професійного українського кіно вже на початку XX століття, так само як свого часу нагадав про пісенне минуле України Порфирій Демуцький.

Висновки. Отже, варто наголосити на високій цінності творчої спадщини Данила Демуцького. За порівняно невеликий період життя йому вдалося досягнути визнання серед колег по знімальному майданчику та у фотоіндустрії. Про надзвичайний талант Демуцького-молодшого актор та кінокритик П. Масоха писав: «Це він - оператор-чарівник, у якого на екрані ніби дихає й співає природа, така жива й неповторна, українська, пахуча, незаймана...» (Масоха, 1970: 132). Будучи за характером скромною та вихованою людиною, Данило Демуцький жодного разу не нарікав на проблеми, які супроводжували його упродовж життя: від невизнання на початку творчого шляху до декількох безпідставних арештів та вигнання за межі рідного краю. Пройшовши тернистий шлях, він досягнув вершини й пішов у небуття тримаючи в руках фотоапарат, який супроводжував його протягом всього життя. Він був одним із тих, хто вірив у свою роботу, подібно батькові жив нею, і які б життєві негаразди не траплялися на кожному етапі його життя, Данило Демуцький впевнено крокував до досягнення своєї мети.

\section{СПИСОК ВИКОРИСТАНИХ ДЖЕРЕЛ I ЛІТЕРАТУРИ}

Антоненко, 2016 - Антоненко А. «Арсенал» покажуть у Великобританії // День. 2016. № 61. URL: https://day.kyiv.ua/uk/article/kultura/arsenal-pokazhut-u-velykobrytaniyi

Безсмертний-Анзіміров, 2016 - Безсмертний-Анзіміров А. Данило Демуцький. Україна Incognita. 2016. URL: http://incognita.day.kyiv.ua/danilo-demuczkij.html

Брюховецька, 2003 - Брюховецька Л. Живе світло Данила Демуцького // Приховані фільми: Укр. кіно 1990-х. Київ : АртЕк, 2003. С. 263-266.

Брюховецька, 2018 - Брюховецька Л. Оператор-чарівник. До 125-річчя Данила Демуцького // КіноТеатр. 2018. № 4. URL: https://ktm.ukma.edu.ua/show_content.php?id=2202

Бундак, 2013 - Бундак О. Сучасна історіографія кінематографу 20-30-х рр. ХХ століття // Літопис Волині [всеукраӥнський науковий часопис]. 2013. Чис. 12. С. 90-96.

Вержбицький, 2013 - Вержбицький Б. Метроном, квітка і таріль // КіноТеатр. 2013. № 4. URL: https://ktm.ukma.edu.ua/show content.php?id=1522 
Вержбицький, 2015 - Вержбицький Б. «Соціально небезпечні елементи» в радянському кіно // Науковий вісник Київського національного університету театру, кіно і телебачення імені І. К. Карпенка-Карого. 2015. Вип. 17. C. 99-104.

Демуцький, 1931 - Матеріали до монографії с. Старосілля / Л. Шульгина, Н. Заглада; мал. Ю. Ю. Павлович; фот.: Д. П. Демуцький, М. П. Сталінський. Київ, 1931. 190 с., арк. іл.: іл.

Дерев’янко, 2001 - Дерев’янко Т. «Монокль» Данила Демуцького // Українська культура. 2001. № 6. С. 28-30.

Кізченко, 2004 - Кізченко В. І. Демуцький Данило Порфирович. Енциклопедія історії України / Редкол.: В. А. Смолій (голова) та ін.: Київ : В-во «Наукова думка», 2004. Т. 2. С. 331.

Кохно, 1965 - Кохно Л. Данило Порфирович Демуцький. Київ : Мистецтво, 1965. 64 с.

Лозовий, 2013 - Лозовий А. Він зробив те, що перевернуло погляд на кіно... // Украйнське слово. 2013. URL: https://ukrslovo.net/doli-ludski/postati/15922.html

Масоха, 1970 - Масоха П. Великий німий на Французькому бульварі. Крізь кінооб'єктив часу. 1970. С. 132.

Пащенко, 2015 - Пащенко А. Візуальні образи історії в кінематографі Радянської України 1920-х років (на прикладі творчості Д. Демуцького) // Науковий вісник Київського національного університету театру, кіно $i$ телебачення імені I. К. Карпенка-Карого. 2015. Вип. 17. С. 93-98.

Попельницька, 2010 - Попельницька О. 100 великих діячів культури України / О. О. Попельницька, М. В. Оксенич. Київ : Арій, 2010. 464 с.: іл.

Тримбач, 2018 - Тримбач С. Космічна вертикаль // День. 2018. № 121 . URL: https://day.kyiv.ua/uk/article/kultura/danylo-demuckyy

Українське німе, 2011 - Данило Демуцький // Украӥнське німе. Ukrainian re-vision : каталог до 90-річчя ВУФКУ. Київ, 2011. С. 294-301.

Фоміченко, 1929 - Фоміченко О. «Два дні» в Америці // Кіно. Двотижневий журнал украӥнської кінематографії. 1929. № 6 (54). С. 2.

Шульгіна, 2016 - Шульгіна А. Педагогічна спадщина кінооператора Олексія Калюжного // Cmyдіï мистеитввознавчі. 2016. Число 3. С. 94-101.

\section{REFERENCES}

Antonenko, 2016 - Antonenko A. «Arsenal» pokazhut u Velykobrytanii [«Arsenal» will be shown in Great Britain] // Den. 2016. № 61. URL: https://day.kyiv.ua/uk/article/kultura/arsenal-pokazhut-u-velykobrytaniyi [in Ukrainian]

Bezsmertnyi-Anzimirov, 2016 - Bezsmertnyi-Anzimirov A. Danylo Demutskyi [Danylo Demutskyi]. Ukraina Incognita. 2016. URL: http://incognita.day.kyiv.ua/danilo-demuczkij.html [in Ukrainian]

Briukhovetska, 2003 - Briukhovetska L. Zhyve svitlo Danyla Demutskoho [The living light of Danylo Demutskyi] // Prykhovani filmy: Ukr. kino 1990-kh. Kyiv : ArtEk, 2003. S. 263-266 [in Ukrainian]

Briukhovetska, 2018 - Briukhovetska L. Operator-charivnyk. Do 125-richchia Danyla Demutskoho [Operatormagician]. KinoTeatr. 2018. № 4. URL: https://ktm.ukma.edu.ua/show_content.php?id=2202 [in Ukrainian]

Bundak, 2013 - Bundak O. Suchasna istoriohrafiia kinematohrafu 20-30-kh rr. KhKh stolittia [Modern historiography of cinema of the 20-30s in the XX century] // Litopys Volyni [vseukrainskyi naukovyi chasopys]. 2013. Chys. 12. S. 90-96 [in Ukrainian]

Verzhbytskyi, 2013 - Verzhbytskyi B. Metronom, kvitka i taril [Metronome, flower and plate] // KinoTeatr. 2013 . № 4. URL: https://ktm.ukma.edu.ua/show content.php?id=1522 [in Ukrainian]

Verzhbytskyi, 2015 - Verzhbytskyi B. «Sotsialno nebezpechni elementy» v radianskomu kino [«Socially dangerous elements» in Soviet cinema] // Naukovyi visnyk Kyivskoho natsionalnoho universytetu teatru, kino i telebachennia imeni I. K. Karpenka-Karoho. 2015. Vyp. 17. S. 99-104 [in Ukrainian]

Demutskyi, 1931 - Materialy do monohrafii s. Starosillia [Materials for the monograph v. Starosillia] / L. Shulhyna, N. Zahlada; mal. Yu. Yu. Pavlovych; fot.: D. P. Demutskyi, M. P. Stalinskyi. Kyiv, 1931. 190 s., ark. il.: il. [in Ukrainian] Derevianko, 2001 - Derevianko T. «Monokl» Danyla Demutskoho [«Monocle» by Danylo Demutskyi] // Ukrainska kultura. 2001. № 6. S. 28-30 [in Ukrainian]

Kizchenko, 2004 - Kizchenko V. I. Demutskyi Danylo Porfyrovych. Entsyklopediia istorii Ukrainy [Demutskyi Danylo Porfyrovych. Encyclopedia of the History of Ukraine] / Redkol.: V. A. Smolii (holova) ta in.: Kyiv : V-vo «Naukova dumka», 2004. T. 2. S. 331 [in Ukrainian]

Kokhno, 1965 - Kokhno L. Danylo Porfyrovych Demutskyi [Demutskyi Danylo Porfyrovych] // Kyiv : Mystetstvo, 1965. 64 s. [in Ukrainian]

Lozovyi, 2013 - Lozovyi A. Vin zrobyv te, shcho perevernulo pohliad na kino... [He did something that turned the view of cinema...] // Ukrainske slovo. 2013. URL: https://ukrslovo.net/doli-ludski/postati/15922.html [in Ukrainian] Masokha, 1970 - Masokha P. Velykyi nimyi na Frantsuzkomu bulvari [Big dumb on the French Boulevard] // Kriz kinoobiektyv chasu. 1970. S. 132. [in Ukrainian]

Pashchenko, 2015 - Pashchenko A. Vizualni obrazy istorii v kinematohrafi Radianskoi Ukrainy 1920-kh rokiv (na prykladi tvorchosti D. Demutskoho) [Visual images of history in the cinema of Soviet Ukraine in the 1920s (on the example of D. Demutskyi)] // Naukovyi visnyk Kyivskoho natsionalnoho universytetu teatru, kino i telebachennia imeni I. K. Karpenka-Karoho. 2015. Vyp. 17. S. 93-98 [in Ukrainian] 
Popelnytska, 2010 - Popelnytska O. 100 velykykh diiachiv kultury Ukrainy [100 great cultural figures of Ukraine] / O. O. Popelnytska, M. V. Oksenych. Kyiv : Arii, 2010. 464 s.: il. [in Ukrainian]

Trymbach, 2018 - Trymbach S. Kosmichna vertykal [Space vertical] // Den. 2018. № 121. URL: https://day.kyiv.ua/uk/article/kultura/danylo-demuckyy [in Ukrainian]

Ukrainske nime, 2011 - Danylo Demutskyi. Ukrainske nime [Danylo Demutskyi. Ukrainian mute] // Ukrainian revision : kataloh do 90-richchia VUFKU. Kyiv, 2011. S. 294-301 [in Ukrainian]

Fomichenko, 1929 - Fomichenko O. «Dva dni» v Amerytsi [«Two days» in America] // Kino. Dvotyzhnevyi zhurnal ukrainskoi kinematohrafii. 1929. № 6 (54). S. 2 [in Ukrainian]

Shulhina, 2016 - Shulhina A. Pedahohichna spadshchyna kinooperatora Oleksiia Kaliuzhnoho [Pedagogical heritage of cinematographer Oleksiy Kaliuzhnyi] // Studii mystetstvoznavchi. 2016. Chyslo 3. S. 94-101 [in Ukrainian] 